\title{
IFN- $\gamma$ Action on Pancreatic Beta Cells Causes Class I MHC Upregulation but Not Diabetes
}

\author{
Helen E. Thomas, ${ }^{\star}$ Jennie L. Parker, ${ }^{\star}$ Robert D. Schreiber, ${ }^{\ddagger}$ and Thomas W.H. Kay ${ }^{\star}$ \\ *Autoimmunity and Transplantation Division, Walter and Eliza Hall Institute of Medical Research, Victoria 3050, Australia; and \\ ${ }^{\ddagger}$ Department of Pathology, Washington University, St. Louis, Missouri 63110
}

\begin{abstract}
We have generated transgenic nonobese diabetic (NOD) mice expressing dominant negative mutant IFN- $\gamma$ receptors on pancreatic beta cells to investigate whether the direct effects of IFN- $\gamma$ on beta cells contribute to autoimmune diabetes. We have also quantitated by flow cytometry the rise in class I MHC on beta cells of NOD mice with increasing age and degree of islet inflammatory infiltrate. Class I MHC expression increases gradually with age in wild-type NOD mice; however, no such increase is observed in the transgenic beta cells. The transgenic mice develop diabetes at a similar rate to that of wild-type animals. This study dissociates class I MHC upregulation from progression to diabetes, shows that the rise in class I MHC is due to local IFN- $\gamma$ action, and eliminates beta cells as the targets of IFN- $\gamma$ in autoimmune diabetes. (J. Clin. Invest. 1998. 102:1249-1257.) Key words: nonobese diabetic mouse - cytokine - autoimmune disease - class I major histocompatibility antigen • transgenic mice
\end{abstract}

\section{Introduction}

Insulin-dependent diabetes mellitus (IDDM) ${ }^{1}$ is characterized by a mixed lymphocytic infiltrate in the pancreatic islets of Langerhans (termed insulitis), followed by beta cell destruction leading to hyperglycaemia. The pleiotropic cytokine IFN- $\gamma$ is detected in the islets in increasing amounts during progression to diabetes in the nonobese diabetic (NOD) mouse and biobreeding $(\mathrm{BB})$ rat models of $\operatorname{IDDM}(1,2)$. Recent data with IFN- $\gamma$ receptor-deficient NOD mice, which do not develop diabetes and have a reduced level of insulitis, confirms that IFN- $\gamma$ has an important pathogenic role in the disease (3).

Address correspondence to Dr. Thomas Kay, Walter and Eliza Hall Institute of Medical Research, Post Office, Royal Melbourne Hospital, Victoria 3050, Australia. Phone: 61-3-9345-2457; FAX: 61-3-93470852; E-mail: kay@wehi.edu.au

Received for publication 23 January 1998 and accepted in revised form 23 July 1998.

1. Abbreviations used in this paper: IDDM, insulin-dependent diabetes mellitus; IFN- $\gamma$, interferon-gamma; NOD, nonobese diabetic; BB, bio-breeding; LCMV-GP, lymphocytic choriomeningitis virus-glycoprotein; RIP, rat insulin promoter; EMSA, electrophoretic mobility shift assay; GAS, IFN- $\gamma$ activated sequence; BC, backcross.

J. Clin. Invest.

(C) The American Society for Clinical Investigation, Inc. 0021-9738/98/09/1249/09 \$2.00

Volume 102, Number 6, September 1998, 1249-1257

http://www.jci.org
However, it is unclear whether the cellular target of IFN- $\gamma$ relevant to diabetes is the beta cell or other cells such as antigen-presenting cells. Treatment of NOD mice with anti-IFN- $\gamma$ antibody or a nonimmunogenic soluble IFN- $\gamma$ receptor prevents disease (4-6), and IFN- $\gamma$-deficient mice crossed with the lymphocytic choriomeningitis virus-glycoprotein (LCMV-GP) mouse model of diabetes are protected from disease after challenge with LCMV (7), which normally activates LCMVGP-specific T cells $(8,9)$. Given the large amount of evidence suggesting involvement of IFN- $\gamma$, it is surprising that IFN- $\gamma-$ deficient NOD mice develop insulitis and diabetes, albeit at a delayed and reduced rate (10).

Many direct effects of IFN- $\gamma$ on beta cells have been demonstrated in vitro, including transcriptional regulation of genes implicated in beta cell dysfunction. The free radical nitric oxide (NO) is produced in beta cells by inducible NO synthase (iNOS), which is induced by IFN- $\gamma$ in combination with IL-1 (for review see reference 11). Upregulation of iNOS by these cytokines leads to inhibition of glucose-stimulated insulin secretion by islets and DNA fragmentation in islet cells (12-14). Fas is a member of the TNF receptor family able to transduce an apoptotic signal (15). Its expression can be induced in vitro by combinations of the cytokines IL-1, IFN- $\gamma$, and TNF- $\alpha$, and once induced, the islets are susceptible to lysis by anti-Fas antibody, demonstrating that Fas-mediated cell death is possible in mouse islets (16). Adhesion molecules such as ICAM-1 are also regulated by IFN- $\gamma$ (17), and may aid in the trafficking of inflammatory mediators to the islets.

Class I major histocompatibility complex (MHC) expression is also upregulated by IFN- $\gamma$, and is induced on beta cells during destructive insulitis. Beta cell class I MHC overexpression is observed in humans (18-20), NOD mice $(21,22)$, and $\mathrm{BB}$ rats (23), and is temporally associated with initiation of insulitis in the LCMV-GP model (24). This upregulation has been proposed as a mechanism for beta cell-specific CD8 ${ }^{+} \mathrm{T}$ cell activation, either by increasing recognition of beta cells by $\mathrm{CD}^{+} \mathrm{T}$ cells, or indirectly by upregulating the antigen-processing pathway (25). Insulitis and diabetes do not occur in beta 2-microglobulin knockout NOD $\left(\mathrm{NOD}_{2} \mathrm{~m}^{\text {null }}\right)$ mice $(26-$ 29) that are deficient in cell surface class I MHC and CD8 ${ }^{+} \mathrm{T}$ cells (30). The absence of insulitis in $\mathrm{NOD}_{2} \mathrm{~m}^{\text {null }}$ mice is consistent with a role for $\mathrm{CD}^{+} \mathrm{T}$ cells and class I MHC expression in the initiation of diabetes in NOD mice. When class I MHC was transgenically reconstituted on beta cells, insulitis returned, suggesting that initiation of autoimmune diabetes in the NOD mouse may involve a direct interaction between $\mathrm{CD}^{+} \mathrm{T}$ cells and peptide-class I MHC complexes on beta cells (31). There is, however, also evidence that $\mathrm{CD}^{+} \mathrm{T}$ cells can be activated by cross-presentation of antigens derived from nonantigen-presenting cells (APCs) in association with class I MHC on professional APCs (32).

The effects of IFN- $\gamma$ on beta cells in vitro and the evidence for its role in vivo have led to the hypothesis that IFN- $\gamma$ may 
promote the course of diabetes in the NOD mouse by acting directly on the beta cell. We have tested this possibility by expressing a dominant negative mutant IFN- $\gamma$ receptor $\alpha$ chain in transgenic mice to generate beta cells that are unresponsive to IFN- $\gamma$. This mutant receptor has been used previously in transgenic mice under the control of $\mathrm{T}$ cell and macrophagespecific promoters to study the effects of IFN- $\gamma$ on these lineages (33). The IFN- $\gamma$ receptor $\alpha$ chain has been truncated intracellularly so that when expressed at high levels, the mutant receptor is able to dimerize with endogenous receptors and bind ligand; however, it is unable to transduce a signal in response to IFN- $\gamma$ (34). We have used this system to study the direct effects of IFN- $\gamma$ on the beta cell while maintaining both an intact immune system and the ability of other islet cells to respond to IFN- $\gamma$. We have found that while IFN- $\gamma$ response is essential for upregulation of class I MHC on beta cells, it is not necessary for insulitis or progression to diabetes in the NOD mouse.

\section{Methods}

Generation of transgenic mice. The rat insulin promoter (RIP) was inserted in place of the human lysozyme promoter in the plasmid BSSK-hLP-myc-mgR $\Delta \mathrm{IC}-\mathrm{hGH}$ (33). The transgene sequence was verified and then excised with KpnI and NotI. C57B1/6 $\times$ SJL F2 embryos were microinjected with the transgene and transferred into pseudopregnant $\mathrm{CBA} \times \mathrm{C} 57 \mathrm{Bl} / 6$ female fosters. Offspring were screened by Southern blot analysis of EcoRI-digested tail DNA using the RIP as a probe. Three founder lines obtained were crossed with NOD/Lt mice (the prevalence of diabetes of these mice at our institution is $70-75 \%$ for females and $15 \%$ for males by $300 \mathrm{~d}$ ) for seven generations with microsatellite analysis for NOD alleles at BC1 and $\mathrm{BC} 2$ generations. One line was intercrossed to generate mice homozygous for the transgene. All mice were housed in the animal facility at the Walter and Eliza Hall Institute of Medical Research.

Microsatellite analysis of back-crossed mice. At the first generation back-cross (BC1), 96 transgene-positive males were tested by microsatellite analysis for the presence of homozygous NOD alleles. A further 29 males were analyzed at the BC2 generation. PCR was performed on genomic DNA using 28 sets of simple sequence length polymorphic markers from the Whitehead Institute collection (35) purchased from Research Genetics (Huntsville, AL). Markers chosen were evenly spaced across the genome. Genotyping was performed as described $(36,37)$. The PCR products were pooled according to size, electrophoresed on a $7 \%$ polyacrylamide, $5.6 \mathrm{M}$ urea, $32 \%$ formamide gel in $1 \times \mathrm{TBE}$, and were then transferred onto a positively charged nylon membrane (Boehringer Mannheim, Mannheim, Germany). Membranes were hybridized with biotinylated oligonucleotide probes and streptavidin-alkaline phosphatase, developed with CDPStar substrate (Boehringer Mannheim, Mannheim, Germany) and exposed to $\mathrm{x}$-ray film for up to $3 \mathrm{~h}$.

Islet isolation. Islets of Langerhans were isolated from mice as previously described (38). The common bile duct was cannulated, and the pancreas was distended with $3 \mathrm{ml}$ of RPMI containing $1.3 \mathrm{U} / \mathrm{ml}$ collagenase $P$ (Boehringer Mannheim). Pooled pancreata were digested at $37^{\circ} \mathrm{C}$ for $20 \mathrm{~min}$, and were then disrupted with shaking. Islets were purified on BSA density gradients (First Link, United Kingdom), washed, and cultured at $37^{\circ} \mathrm{C}$ in $10 \% \mathrm{CO}_{2}$ in DME containing $2.5 \mathrm{mM}$ glucose, penicillin, streptomycin, and 10\% FCS. Murine IFN- $\gamma$ (Genentech Inc., South San Francisco, CA) was added to the medium as indicated at a final concentration of $100 \mathrm{U} / \mathrm{ml}$ unless stated otherwise. Islets were dispersed into single cells with $0.2 \%$ trypsin (Calbiochem Corp., La Jolla, CA), $10 \mathrm{mM}$ EDTA in HBSS, and were allowed to recover in culture medium for $1 \mathrm{~h}$ before staining with $\mathrm{mAb}$.

Antibodies. Biotinylated 9E10, which recognizes the myc epitope at the $5^{\prime}$ end of the transgene, was used for detection of the mutant IFN- $\gamma$ receptor (39), and GR20 rat mAb was used for detection of the murine IFN- $\gamma$ receptor $\alpha$ chain (40). To stain class I MHC, 34-1-2s, a mouse $\mathrm{IgG} 2 \mathrm{a} \mathrm{mAb}$ directed against $\mathrm{H}-2 \mathrm{~K}^{\mathrm{d}}$ and $\mathrm{D}^{\mathrm{d}}$, which cross-reacts with $\mathrm{H}-2 \mathrm{~K}^{\mathrm{b}}$ and s, r, q, p H-2 haplotypes (41), was used. A2B5, a monoclonal IgM antiganglioside (42) obtained from American Type Culture Collection (Rockville, MD), was used in some instances for detecting islet endocrine cells by flow cytometry.

Flow cytometry. Islet cell suspensions were incubated for $30 \mathrm{~min}$ on ice with $\mathrm{mAb}$ diluted in balanced salt solution (BSS) containing $2 \%$ FCS. They were then washed and incubated for $15 \mathrm{~min}$ with a secondary $\mathrm{Ab}$ as necessary. Second antisera used were as follows: biotinylated anti-rat Ig (PharMingen, San Diego, CA) followed by phycoerythrin-conjugated streptavidin (Caltag Labs, San Francisco, CA) and phycoerythrin-conjugated anti-mouse Ig (Silenus Labs Pty., Ltd., Hawthorn, Australia). Cells were finally washed and resuspended in BSS with $2 \%$ FCS and $1 \mu \mathrm{g} / \mathrm{ml}$ propidium iodide to stain dead cells. Analysis was performed on a FACScan (Becton Dickinson, Mountain View, CA). Beta cells were sorted on a FACStar ${ }^{\text {plus }}$ (Becton Dickinson) on the basis of flavin adenine dinucleotide autofluorescence according the method described (43).

Immunohistochemistry. Pancreas and spleen were dissected, snapfrozen in OCT (Miles-Yeda Inc., Elkhart, IN) in a hexane/liquid nitrogen bath, and stored at $-70^{\circ} \mathrm{C}$. Serial $5-\mu \mathrm{m}$ cryostat sections were cut, fixed in acetone, air-dried, and stored at $-20^{\circ} \mathrm{C}$. Immunohistochemical staining was performed using an avidin-biotin immunoperoxidase technique. Endogenous biotin present in pancreas exocrine tissue was blocked using an avidin/biotin blocking kit (Vector Laboratories, Inc., Burlingame, CA) and additional blocking with $10 \%$ mouse serum. Incubations were for $30 \mathrm{~min}$ followed by a 10-min wash in PBS. Insulin was detected by incubation with guinea pig anti-insulin $\mathrm{Ab}$ followed by incubation with horseradish peroxidase-conjugated anti-guinea pig Ig (Dako Corp., Santa Barbara, CA). The $\Delta \gamma \mathrm{R}$ transgene was detected with biotinylated 9E10 followed by streptavidin-conjugated horseradish peroxidase. Stains were developed for 4 min with 3,3'-diaminobenzidine tetrahydrochloride (Sigma Chemical Co., St. Louis, MO) at $1 \mathrm{mg} / \mathrm{ml}$ in PBS containing $0.02 \%$ hydrogen peroxide and counterstained with hematoxylin.

Electrophoretic mobility shift assay (EMSA). Nuclear extracts were prepared by a method adapted from Schreiber (44). Cells were lysed in a buffer containing $10 \mathrm{mM}$ Hepes, $\mathrm{pH} 7.9,10 \mathrm{mM} \mathrm{KCl}, 1.5 \mathrm{mM}$ $\mathrm{MgCl}_{2}$, protease inhibitors ( $0.5 \mathrm{mM}$ PMSF, $10 \mu \mathrm{g} / \mathrm{ml}$ leupeptin), and $0.5 \mathrm{mM}$ DTT. The lysate was vortexed with $25 \mu \mathrm{l} 10 \% \mathrm{NP} 40$, and was centrifuged. The pellet was incubated on ice in $420 \mathrm{mM} \mathrm{NaCl}, 20 \mathrm{mM}$ Hepes, pH 7.9, $1.5 \mathrm{mM} \mathrm{MgCl} 2,0.2 \mathrm{mM}$ EDTA, glycerol, protease inhibitors, and DTT, and was then centrifuged at 12,000 rpm for $5 \mathrm{~min}$ at $4^{\circ} \mathrm{C}$. Nuclear extracts were stored at $-70^{\circ} \mathrm{C}$. EMSA were carried out using oligonucleotides labeled with ${ }^{32} \mathrm{P} .1 \mathrm{pmol}$ of annealed doublestranded oligonucleotide was labeled by filling in the ends with Klenow polymerase and $\left[{ }^{32} \mathrm{P}\right] \alpha-\mathrm{dATP}$, and the labeled probe was purified on a spin column. The sequence used was the IFN- $\gamma$-activated sequence (GAS; from the Fc $\gamma \mathrm{R} 1$ gene promoter [45]): 5'-GTACGAGATGTATTTCCCAGAAAA. For the EMSA, $4 \mu \mathrm{l}$ of nuclear extract was incubated on ice in a reaction containing $13.3 \mathrm{mM}$ Hepes,

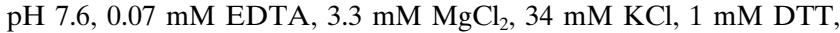
$10 \%$ glycerol, and $0.5 \mu \mathrm{g}$ poly $(\mathrm{dI}-\mathrm{dC})$. After $15 \mathrm{~min}, 15,000 \mathrm{cpm}$-labeled probe was added. After a further $15 \mathrm{~min}$, the DNA-protein complexes were analyzed by electrophoresis on a $5 \%$ nondenaturing polyacrylamide gel in $0.25 \times \mathrm{TBE}$ and exposure to $\mathrm{x}$-ray film (Hyperfilm-MP; Amersham International, Little Chalfont, United Kingdom).

Histological scoring and diabetes incidence. Pancreas and spleen were dissected from mice at 50 and $90 \mathrm{~d}$ of age and placed into Bouin's fixative. 5- $\mu \mathrm{m}$ paraffin-embedded sections were cut and stained with hemotoxylin and eosin. Insulitis was scored on three sections cut $40 \mu \mathrm{m}$ apart on a $0-4$ scale as described (46). Three mice were analyzed per group, with $\sim 100$ islets scored in each group.

For adoptive transfer, diabetogenic spleen cells were purified from NOD mouse donors with blood glucose levels $>15 \mathrm{mmol} / \mathrm{liter}$. 
Splenocytes were suspended at $1 \times 10^{8}$ cells/ml in RPMI, and $200 \mu \mathrm{l}$ was injected intravenously into irradiated recipient mice. Eight male transgenic and eight nontransgenic mice aged $82 \mathrm{~d}$ were used as recipients. Blood glucose was measured every $5 \mathrm{~d}$ starting $2 \mathrm{wk}$ after transfer. Mice were considered diabetic when blood glucose exceeded 15 $\mathrm{mmol} /$ liter.

Male mice (eight mice per group) $>100 \mathrm{~d}$ of age were used to assess the incidence of cyclophosphamide-accelerated diabetes. A single dose of $300 \mathrm{mg} / \mathrm{kg}$ body weight of cyclophosphamide (Cycloblastin Farmitalia; Carloerba, Hawthorn, Australia) was injected intraperitoneally, and blood glucose levels were monitored weekly starting $2 \mathrm{wk}$ after cyclophosphamide.

Female transgenic and nontransgenic mice (15-30 per group) were set aside to assess the spontaneous incidence of diabetes. After $120 \mathrm{~d}$ of age, the mice were monitored weekly by urine glucose measurement with a follow-up blood glucose determination if required. Mice were considered diabetic with a blood glucose over $15 \mathrm{mmol} / \mathrm{liter}$.

\section{Results}

Generation of dominant-negative IFN- $\gamma$ receptor transgenic mice. To generate mice with beta cells resistant to IFN- $\gamma$, we used a dominant negative form of the IFN- $\gamma$ receptor $\alpha$ chain. The mutant IFN- $\gamma$ receptor $\alpha$ chain $(\Delta \gamma \mathrm{R})$ was truncated intracellularly so that it lacks the binding sites for Jak protein tyrosine kinases and Stat1, thus acting as a dominant negative receptor when expressed at high levels compared with endogenous receptors (34). Transgene expression was detected with an epitope from the myc proto-oncogene, recognized by the $\mathrm{mAb} 9 \mathrm{E} 10$. The gene was cloned under the control of the rat insulin promoter (RIP- $\Delta \gamma \mathrm{R}$ ), and was microinjected into $\mathrm{C} 57 \mathrm{Bl} / 6 \times \mathrm{SJL}$ F2 embryos. Three independent transgenic lines were obtained, all expressing $\Delta \gamma \mathrm{R}$ protein in beta cells. All three lines were back-crossed onto the NOD genetic background.

One line (line 10) was chosen for accelerated back-cross onto $N O D$, which was achieved by microsatellite analysis of male mice at back-cross $1(\mathrm{BC} 1)$ and $\mathrm{BC} 2$ generations. Mice heterozygous for the transgene were analyzed with 28 microsatellite markers spread across the genome. Founder males at each generation were chosen as those with the greatest number of homozygous NOD alleles so that the $\mathrm{BC} 2$ progenitor male was $93 \%$ homozygous for those alleles tested, including a marker within the MHC region, the major diabetes susceptibility locus. The mice were then randomly back-crossed a further five times to obtain $\mathrm{BC} 7$ mice. Transgenic and nontransgenic animals were intercrossed to generate mice homozygous for the transgene and control animals with the same degree of NOD genetic background. Although it is possible with such a genome screen to identify the transgene location, we did not find any linkage in our study, probably due to the relatively small number of markers tested per chromosome.

Expression of RIP- $\Delta \gamma R$ in beta cells. The $\mathrm{mAb} 9 \mathrm{E} 10$ recognizing the myc epitope tag (39) was used to detect expression of the $\Delta \gamma \mathrm{R}$ mutant receptor in pancreas sections from transgenic mice by immunohistochemistry. Transgene expression was detected in the islets of transgenic mice, but not in the surrounding exocrine pancreas, nor in the islets of littermate control animals (Fig. $1 A$ ). The relative level of expression on the three lines of mice generated was compared by staining purified islet cells with 9E10, and by analysis by flow cytometry. The three lines showed similar levels of transgene expression (Fig. $1 B$ ).
The expression of IFN- $\gamma$ receptors on the beta cells of RIP$\Delta \gamma \mathrm{R}$ mice was also examined using the mAb GR20 that recognizes both the endogenous and transgenic murine IFN- $\gamma$ receptors (40). Fig. $1 C$ shows levels of expression in mice wildtype, heterozygous, and homozygous for the mutant receptor. The level of GR20 staining is greatly increased in the beta cells of mice homozygous for the RIP- $\Delta \gamma \mathrm{R}$ gene, possibly due to the lack of turnover of the mutant receptor within the cell.

Stat1 is not activated in beta cells of RIP- $\Delta \gamma R$ mice. As a measure of IFN- $\gamma$ responsiveness, we first looked at the ability of the transcription factor Stat1 to bind DNA in response to IFN- $\gamma$. Stat1 normally binds to the IFN- $\gamma$ receptor $\alpha$ chain where it is phosphorylated by members of the Janus (Jak) family of tyrosine kinases. It then forms homodimers and translocates to the nucleus where it binds to the specific DNA sequence termed the gamma-activated sequence (GAS). When bound to the GAS, Stat1 dimers are able to regulate IFN- $\gamma$-responsive genes transcriptionally (for review see reference 47). To analyze the activation of Stat 1 in the RIP- $\Delta \gamma \mathrm{R}$ mice, beta cells were purified by FACS sorting of the A2B5-positive (endo-
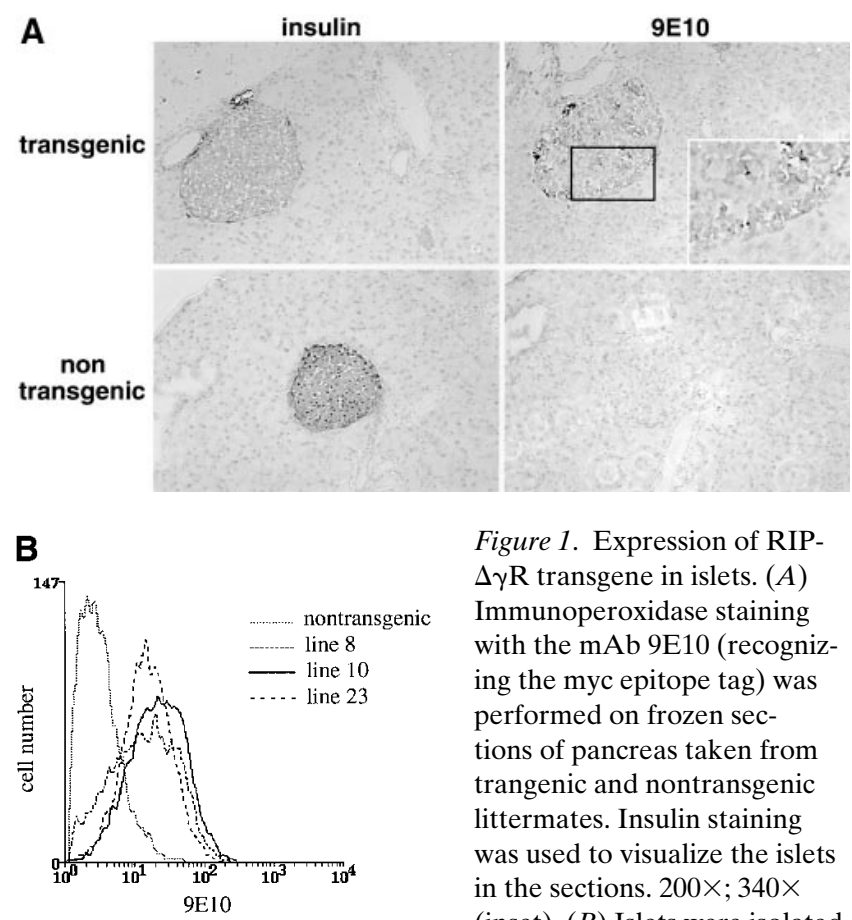

Figure 1. Expression of RIP$\Delta \gamma \mathrm{R}$ transgene in islets. $(A)$ Immunoperoxidase staining with the mAb 9E10 (recognizing the myc epitope tag) was performed on frozen sections of pancreas taken from trangenic and nontransgenic littermates. Insulin staining was used to visualize the islets in the sections. $200 \times ; 340 \times$ (inset). ( $B$ ) Islets were isolated from two mice of each of the three transgenic lines generated and nontransgenic littermates. Islet cell suspensions were stained with the biotinylated $\mathrm{mAb} 9 \mathrm{E} 10$ and streptavidin-phycoerythrin, and were analyzed by flow cytometry. (C) Islets isolated from nontransgenic NOD/Lt, heterozygous (RIP- $\Delta \gamma \mathrm{R}[+/-]$ ), and ho-

mozygous (RIP- $\Delta \gamma \mathrm{R}[+/+])$ transgenic mice were dispersed and analyzed by flow cytometry with the rat anti-IFN- $\gamma$ receptor $\mathrm{mAb}$ (GR20), and were then detected with biotinylated anti-rat Ig and streptavidin-phycoerythrin. Staining is shown on beta cells identified by autofluorescence. 


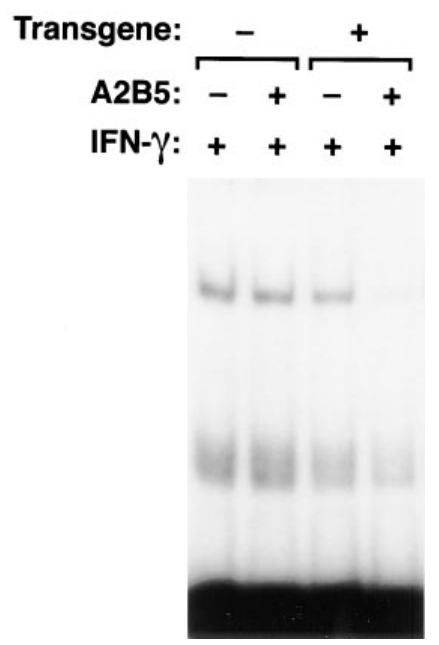

Figure 2. Stat1 is not activated in purified beta cells from RIP$\Delta \gamma \mathrm{R}$ mice. Islet cells from transgenic and nontransgenic littermates were sorted by flow cytometry into endocrine (FITC-A2B5+) and nonendocrine (FITC-A2B5-) populations. Cells were treated with $100 \mathrm{U} / \mathrm{ml} \mathrm{IFN}-\gamma$ for $15 \mathrm{~min}$, and nuclear extracts prepared and EMSA carried out with radiolabeled GAS oligonucleotide probe.

crine) and A2B5-negative (nonendocrine) cells. The cells were treated with $100 \mathrm{U} / \mathrm{ml}$ IFN- $\gamma$ for $15 \mathrm{~min}$ before nuclear extract preparation. Nuclear extracts were analyzed by EMSA for the presence of Stat1 DNA-binding activity. While Stat1 is activated by IFN- $\gamma$ in the nontransgenic beta cells, the heterozygous transgenic mice have a greatly reduced level of Stat1 DNA binding (Fig. 2). The small amount of Stat1 DNA binding in the heterozygous mice could be due to insufficient levels of the transgene expression to achieve the dominant negative effect, or due to the use of a very high level of IFN- $\gamma$, causing a small response (see below).

Class I MHC is not upregulated on RIP- $\Delta \gamma R$ beta cells. We next looked at the ability of IFN- $\gamma$ to upregulate a responsive gene in the transgenic beta cells. It is well-documented that surface expression of class I MHC on beta cells increases in response to IFN- $\gamma$. We analyzed the expression of class I MHC on beta cells by flow cytometry after incubation of purified islets in vitro for $48 \mathrm{~h}$ with $100 \mathrm{U} / \mathrm{ml}$ IFN- $\gamma$. The nontransgenic beta cells showed a rise in cell surface class I MHC expression after incubation with IFN- $\gamma$, which was reduced in the mice homozygous for the transgene (Fig. $3 A$ ). There was a slight but reproducible increase in class I MHC levels in the transgenic mice after incubation with $100 \mathrm{U} / \mathrm{ml}$ IFN- $\gamma$ that could be due to contaminating non-beta cells in the flow cytometry analysis or to the high concentration of IFN- $\gamma$ during the 48- $h$ in vitro culture. To address the issue of IFN- $\gamma$ concentration, we looked at class I MHC expression after incubation with varying doses of IFN- $\gamma$, from $0.1 \mathrm{U} / \mathrm{ml}$ to $1,000 \mathrm{U} / \mathrm{ml}$. Nontransgenic beta cells responded to as low as $1 \mathrm{U} / \mathrm{ml}$ IFN- $\gamma$ with maximal upregulation of class I MHC after $10 \mathrm{U} / \mathrm{ml}$. The RIP- $\Delta \gamma \mathrm{R}$ beta cells did not upregulate class I MHC in response to $10 \mathrm{U} / \mathrm{ml}$ IFN- $\gamma$; however, they showed a slight increase in class I MHC with $100 \mathrm{U} / \mathrm{ml}$ IFN- $\gamma$ (Fig. $3 A$ ), which was not further increased with up to $1,000 \mathrm{U} / \mathrm{ml}$ IFN- $\gamma$ (not shown). Therefore, it is likely that with in vivo concentrations of IFN- $\gamma$, the RIP- $\Delta \gamma \mathrm{R}$ beta cells are not able to respond to IFN- $\gamma$, even though with high levels of cytokine in vitro class I $\mathrm{MHC}$ is minimally upregulated (see results below also). Basal level of class I MHC on transgenic islets was not reduced as compared with the wild-type mice, demonstrating that IFN- $\gamma$ responsiveness is not required for basal class I MHC expression in beta cells.

Quantitation of class I MHC expression increase with age on beta cells. Class I MHC surface protein levels were analyzed on A2B5-positive islet endocrine cells isolated from NOD mice ranging in age from $27 \mathrm{~d}$ at the start of insulitis to $120 \mathrm{~d}$ when mice are developing diabetes. Class I MHC levels continued to gradually increase from $50 \mathrm{~d}$ of age with no definite evidence of a plateau to this effect or step-wise change at the time that diabetes presents (Fig. $4 A$ ). No difference was seen in female and male mice at any age tested despite the well-recognized difference in risk of developing diabetes (Fig. 4 B). Staining on three consecutive days of islet cells isolated at the same time showed that class I MHC levels were stable in vitro for at least $48 \mathrm{~h}$ (not shown).

NOD.scid mice do not develop insulitis or diabetes, but are congenic with NOD mice; that is, the genes controlling autoimmunity, including MHC genes, are the same as in NODs. D2.GD mice have the same class I MHC genes as NOD mice, but have different class II MHC and other genes, and are not prone to autoimmunity. We used these two strains of mice to ask whether the increase in class I MHC expression requires

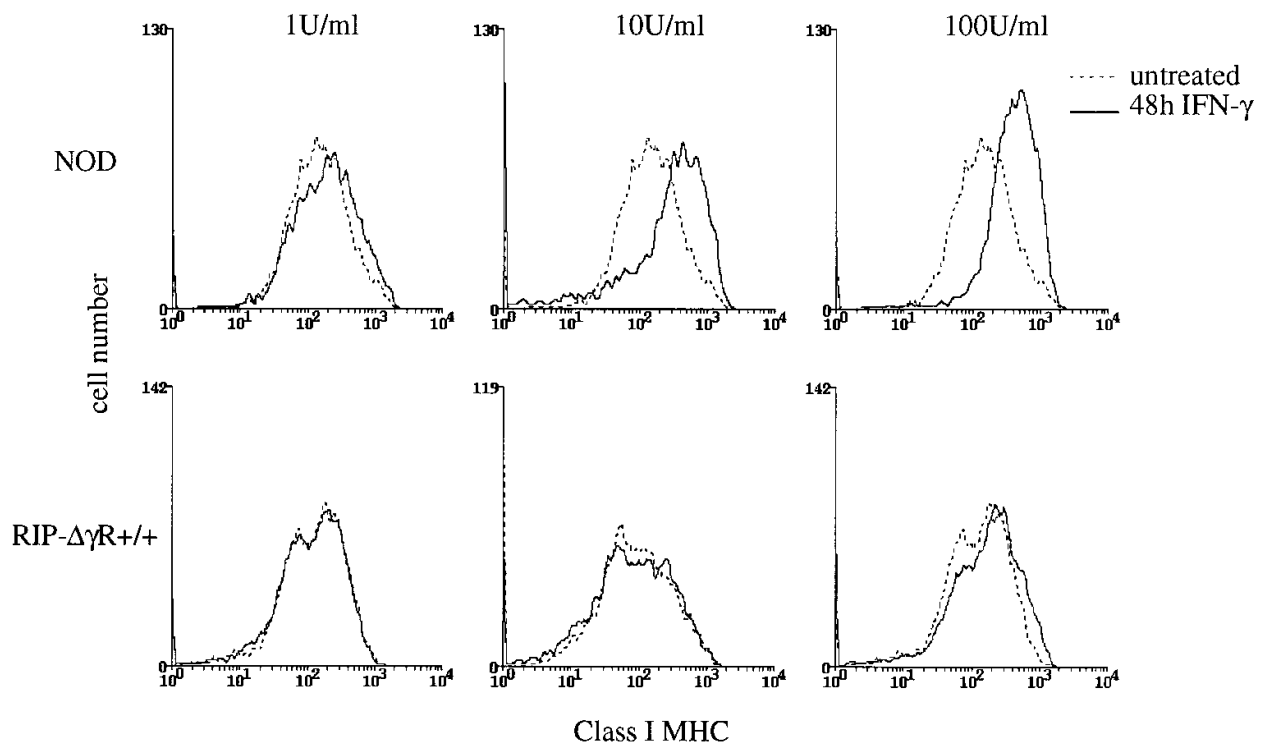

Figure 3. Dose response of IFN- $\gamma$ on RIP- $\Delta \gamma \mathrm{R}$ beta cells in vitro. Islets isolated from nontransgenic NOD/Lt mice or RIP- $\Delta \gamma \mathrm{R}(+/+)$ mice were cultured for $48 \mathrm{~h}$ in the absence or presence of IFN- $\gamma$ at the indicated concentrations. Class I MHC was stained with the mAb 341-2s followed by phycoerythrin antimouse Ig, and is shown for the autofluorescent beta cell population of the islet cell suspension. 
A
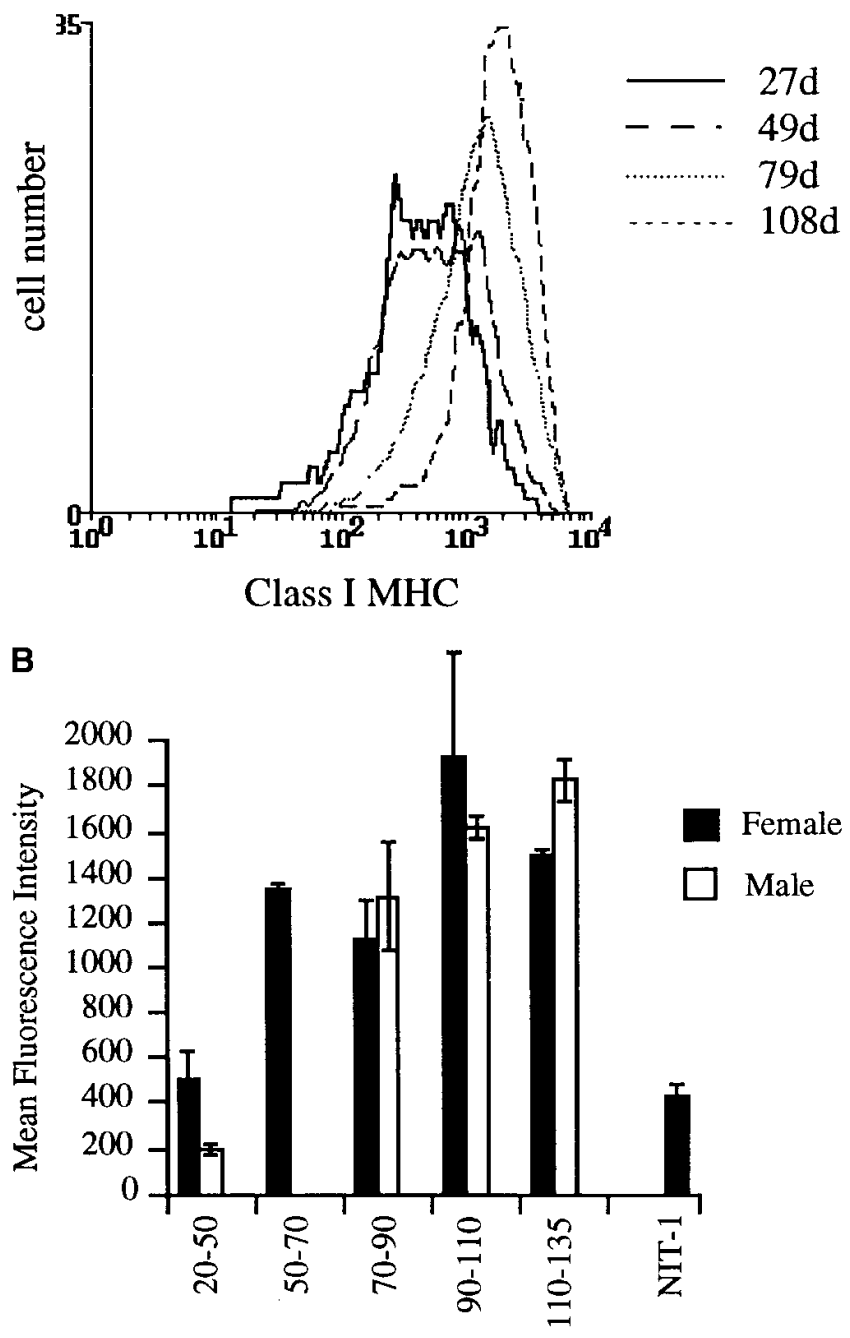

Age (days)

Figure 4. Class I MHC expression increases with age on NOD/Lt beta cells. ( $A$ ) Islet cells from NOD/Lt mice of 27, 49, 79, and $108 \mathrm{~d}$ of age were stained with 34-1-2s and phycoerythrin anti-mouse Ig for class I MHC expression. Beta cells are shown in this figure, identified with the mAb A2B5-FITC. (B) Class I MHC staining on A2B5+ islet cells from female (solid bars) and male (open bars) NOD mice of the age groups indicated. The results represent the mean fluorescence intensity $+/-$ SEM for three to four individual experiments, where islets from four to six mice of the same age have been pooled in each experiment. The NIT-1 insulinoma cell line (53) was included in each experiment to control for variability of class I MHC expression.

the presence of insulitis. No increase in class I MHC expression with age was seen in either NOD.scid or D2.GD islet cells (Fig. 5, $A$ and $B$ ), and the levels seen were similar to those on islet cells from young NOD mice before or at the time of insulitis. These results are consistent with overexpression of class I MHC being secondary to cytokines produced by cells in the insulitis lesion.

To determine if the rise in surface class I MHC expression seen in NOD mice of increasing age is due to the effect of local IFN- $\gamma$ action on beta cells, we analyzed RIP- $\Delta \gamma \mathrm{R}$ mice at ages after the onset of insulitis and compared beta cell class I MHC expression with that of NOD mice of similar age. NOD.scid
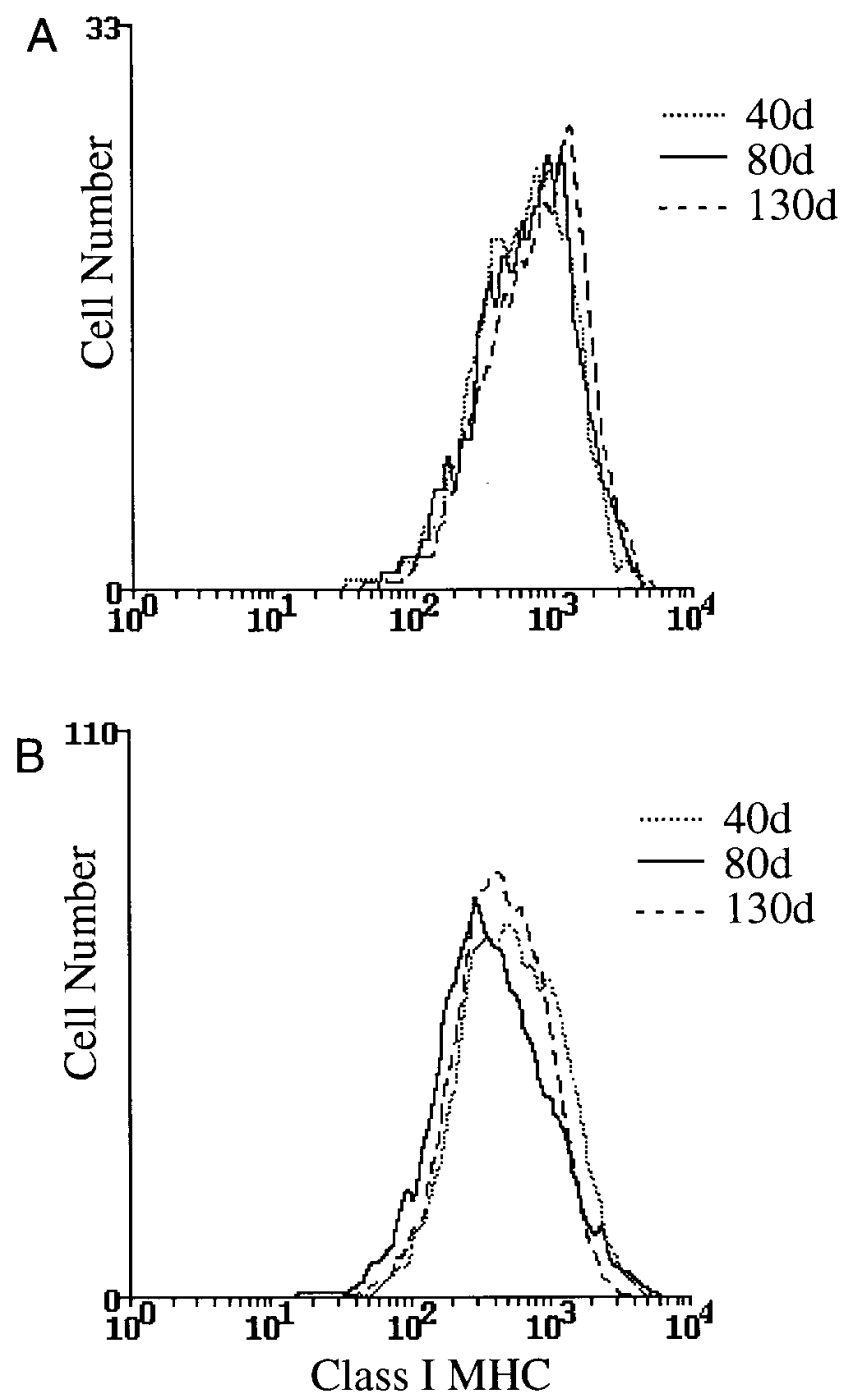

Figure 5. Class I MHC expression does not increase with age on islet cells in the absence of insulitis. Islet cells from $(A)$ NOD.scid and $(B)$ D2.GD mice 40, 80, and $130 \mathrm{~d}$ of age were stained with the mAb 34-1-2s and phycoerythrin anti-mouse Ig for class I MHC expression. Beta cells were identified with the mAb A2B5-FITC.

mice were used as an insulitis-free baseline class I MHC expression level. The class I MHC level of beta cells from RIP$\Delta \gamma \mathrm{R}$ mice of ages 72-99 d remained unchanged at the level seen in NOD.scid beta cells, whereas the class I MHC level on beta cells of 116-d-old NODs was elevated (Fig. 6). These data suggest that the class I MHC increase in NODs is due to effects of local IFN- $\gamma$. This result further demonstrates that beta cells from the transgenic mice are not responsive to IFN- $\gamma$ in vivo. While it is conceivable that other IFN- $\gamma$-responsive genes may be regulated in the transgenic beta cells via an alternative signaling pathway, we have found no evidence for this.

Diabetic spleen cells transfer disease into RIP- $\Delta \gamma R$ recipients. We next looked at the ability of diabetogenic spleen cells to transfer disease into RIP- $\Delta \gamma \mathrm{R}$ recipients. After transfer of $2 \times 10^{7}$ splenocytes from diabetic donors into irradiated RIP$\Delta \gamma \mathrm{R}(+/+)$ or NOD mice, diabetes incidence was assessed by regular blood glucose measurements. The incidence of diabetes was the same in the transgenics and control NOD mice 


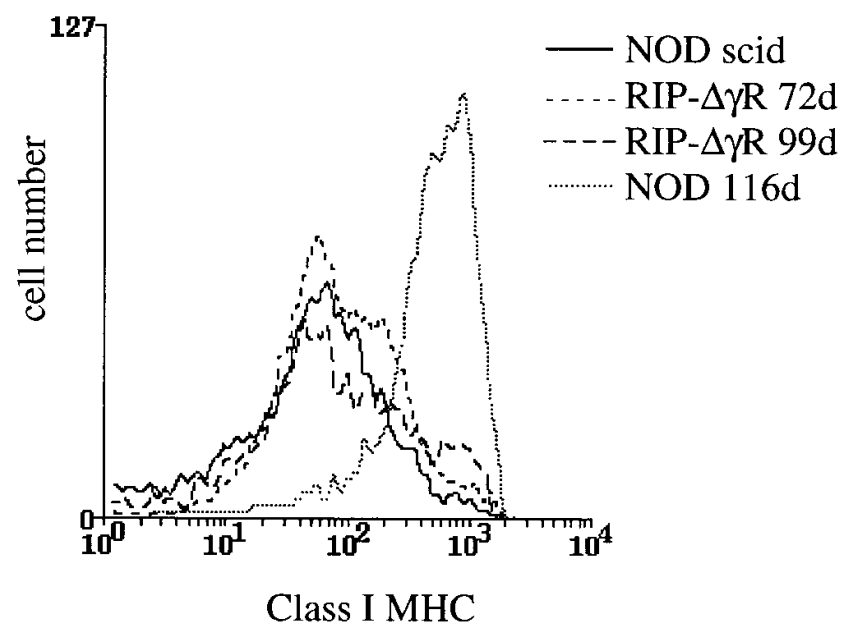

Figure 6. Class I MHC expression does not increase with age on RIP$\Delta \gamma \mathrm{R}$ beta cells. Islet cells from NODscid, 116-d-old NOD/Lt, 72-, and 99-d-old RIP- $\Delta \gamma \mathrm{R}(+/+)$ mice were stained with the mAb 34-1-2s and phycoerythrin anti-mouse Ig for class I MHC expression. Shown is the class I MHC staining on the autofluorescent beta cell population.

(Fig. 7). Thus, beta cell responsiveness to IFN- $\gamma$ is not necessary for the effector phase of beta cell destruction.

Insulitis and accelerated diabetes remain unchanged in RIP$\Delta \gamma R$ mice. Insulitis scoring was done with homozygous mice at 50 and $90 \mathrm{~d}$ of age. We found no significant difference between the insulitis scores of the transgenic and nontransgenic animals (Table I). RIP- $\Delta \gamma \mathrm{R}(+/+)$ and NOD controls were given a single injection of $300 \mathrm{mg} / \mathrm{kg}$ cyclophosphamide to determine the incidence of accelerated diabetes. Blood glucose levels were monitored weekly, and no difference $(P=0.255$, logrank test) was found between cyclophosphamide-accelerated diabetes in the transgenic and nontransgenic animals (Fig. 8).

Spontaneous incidence of diabetes in RIP- $\Delta \gamma R$ mice. Finally, the effect of beta cell unresponsiveness to IFN- $\gamma$ on the spontaneous incidence of diabetes was determined. Fig. 9 shows the survival curve for transgenic vs. nontransgenic females, with a mean followup age of $185 \mathrm{~d}$. We found no significant difference in progression to diabetes between the wild-type and transgenic mice, with a $P=0.7$ by the logrank test. We conclude that beta cell responsiveness to IFN- $\gamma$ is not required for development of autoimmune diabetes in the NOD mouse.

\section{Discussion}

In this study we have described transgenic NOD mice with beta cells that are unresponsive to IFN- $\gamma$. These mice develop insulitis and diabetes at the same rate as nontransgenic littermates, showing that IFN- $\gamma$ does not promote the progression of autoimmune diabetes in the NOD by directly affecting beta cell viability or gene expression, but must act indirectly via another cell type. These mice also show that IFN- $\gamma$ is responsible for increased beta cell class I MHC expression in NOD mice, a pathological feature of IDDM seen in affected humans and $\mathrm{BB}$ rats as well. Therefore, increased class I MHC expression on beta cells is not required for progression of diabetes.

We and others have linked in vitro effects on beta cells of

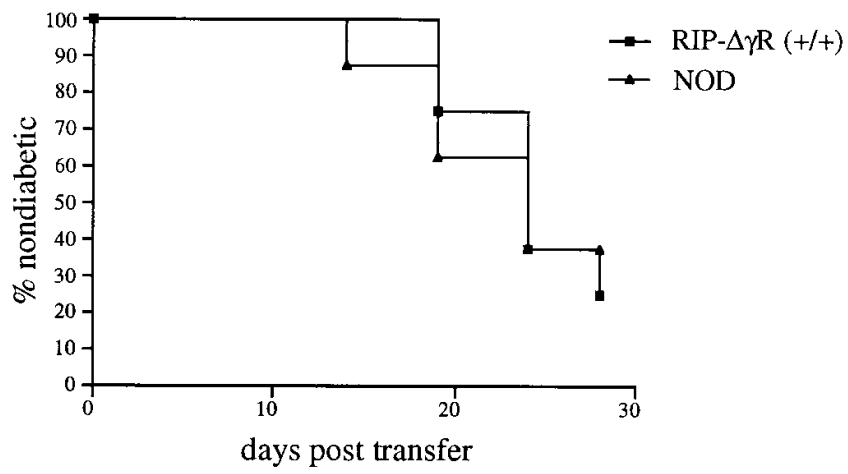

Figure 7. Adoptive transfer of diabetes into RIP- $\Delta \gamma \mathrm{R}$ recipients. Splenocytes from diabetic NOD/Lt female donors were injected intravenously into irradiated NOD/Lt or RIP- $\Delta \gamma \mathrm{R}(+/+)$ recipients. The percentage of mice free from disease is shown up to 28 days post transfer. Eight mice were used per group.

IFN- $\gamma$ and other cytokines to the pathogenesis of diabetes (for reviews see references $48-50$ ). While plausible circumstantial evidence for this link has existed, it has not previously been directly tested. These in vitro effects remain valid, but they do not explain the ability of IFN- $\gamma$ to promote diabetes. If direct effects of IFN- $\gamma$ do play a role, it must be minor because spontaneous disease and diabetes development in two accelerated models of diabetes were not affected by transgene expression. This finding is important because of the emphasis placed on in vitro effects of IFN- $\gamma$ on beta cells in diabetes research, which we now believe to be of limited relevance.

Class I MHC expression on pancreatic beta cells and progression to autoimmune diabetes have been linked in humans, $\mathrm{BB}$ rats, and NOD mice. In the current study they have been dissociated for the first time because RIP- $\Delta \gamma \mathrm{R}$ mice developed diabetes without beta cell class I overexpression. This result suggests that basal levels of class I expression are sufficient for $\mathrm{CD} 8^{+} \mathrm{T}$ cell recognition of beta cells, known to be required for diabetes in the NOD mouse model (51).

Class I MHC overexpression on beta cells is closely associated with insulitis, and is upregulated very close to the time that insulitis begins. It is not found by immunohistology in islets without insulitis (21). In the current study, class I MHC overexpression on NOD beta cells has been quantitated for the first time by flow cytometry. Increased expression of class I MHC was first recognized at $50 \mathrm{~d}$ of age, and mean class I expression then rose gradually with age until 90-110 d when hy-

Table I. Histological Scoring of Insulitis in Nondiabetic Wild-type NOD/Lt and RIP- $\Delta \gamma R(+/+)$ Mice

\begin{tabular}{lccc}
\hline & No insulitis & $\begin{array}{c}\text { Noninvasive } \\
\text { insulitis }\end{array}$ & $\begin{array}{c}\text { Destructive } \\
\text { insulitis }\end{array}$ \\
\hline NOD 50 d & 86.7 & 12 & 1.3 \\
RIP- $\Delta \gamma$ R 50 d & 88.6 & 10.1 & 1.3 \\
NOD 90 d & 37.2 & 33.3 & 29.5 \\
RIP- $\Delta \gamma$ R 90 d & 39.1 & 38.3 & 22.6 \\
& & & \\
\hline
\end{tabular}

Three mice were analyzed per group. The score is the percentage of islets in each category. At least 100 islets were scored per group. 


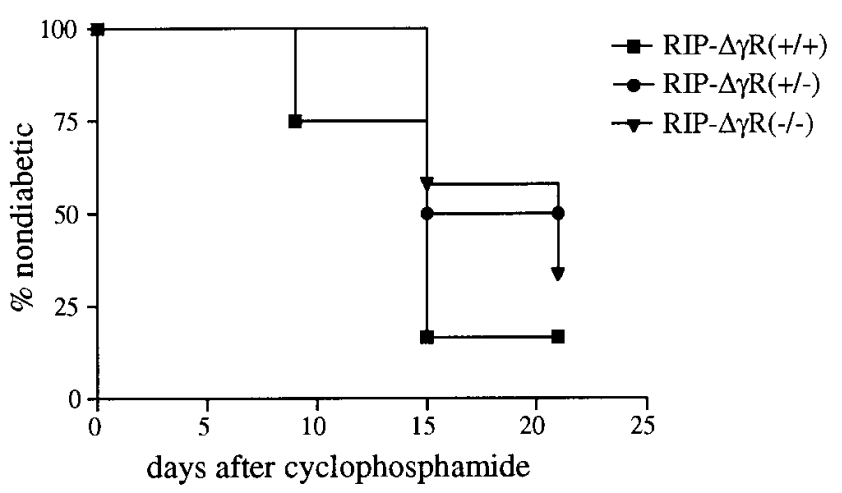

Figure 8. Cyclophosphamide induces diabetes in RIP- $\Delta \gamma \mathrm{R}$ mice. Nondiabetic male mice were given a single dose of cyclophosphamide injected intraperitoneally at $300 \mathrm{mg} / \mathrm{kg}$ body weight, and were observed for hyperglycemia development. The percentage of nondiabetic mice after cyclophosphamide injection of RIP- $\Delta \gamma \mathrm{R}(+/+)$, RIP$\Delta \gamma \mathrm{R}(+/-)$, and nontransgenic littermates is shown. Eight mice were included in each group. The curves were not significantly different by the logrank test with a $P=0.255$.

perglycaemia began to occur. We did not observe increased class I MHC expression before insulitis, and therefore it is likely to be a consequence of rather than required for its development. This conclusion was supported by the absence of increased class I expression with age in mice without insulitis, and the development of insulitis in RIP- $\Delta \gamma \mathrm{R}$ mice in the absence of class I MHC overexpression. Similarly, increased class I expression is not likely to be due to the class I genes of the NOD since D2.GD mice with identical class I type do not show this phenotype. In contrast, total absence of class I MHC expression in the $\mathrm{NOD}_{2} \mathrm{~m}^{\text {null }}$ completely protects NOD mice from insulitis (for review see reference 51). We did not find any difference between class I MHC expression on beta cells from male and female NOD mice, making it also likely that class I overexpression is not sufficient for progression to diabetes since male mice in our colony rarely develop diabetes.

Our study shows that IFN- $\gamma$ is the major factor associated with increased class I MHC expression on NOD beta cells. Other cytokines, endogenous or exogenous viruses, diet, or other environmental agents, although possibly contributing indirectly to this phenomenon, are unlikely to have a direct effect. This result is not surprising as, in vitro, IFN- $\gamma$ is the only agent we have used that increases beta cell class I to the extent seen in vivo in NOD mice. An important implication of this result is that beta cell class I can be regarded as a local indicator of IFN- $\gamma$ action. If this is the case, our data do not support a sudden shift to local IFN- $\gamma$ activity, but rather a gradual rise with age.

The IFN- $\gamma$ knockout mice develop diabetes at a modestly reduced and delayed rate (10). It is conceivable that global IFN- $\gamma$ deficiency results in the development of compensatory mechanisms that preserve immune homeostasis, and also substitute for IFN- $\gamma$ in the pathogenesis of diabetes. In contrast, IFN- $\gamma$ receptor knockout NOD mice fail to develop diabetes, and the results indicate that this is likely to be due to the absence of IFN- $\gamma$-responsive macrophages or beta cells rather than T cells (3). The discrepancy between these results is unexplained, but both mice are known to have abnormal immune

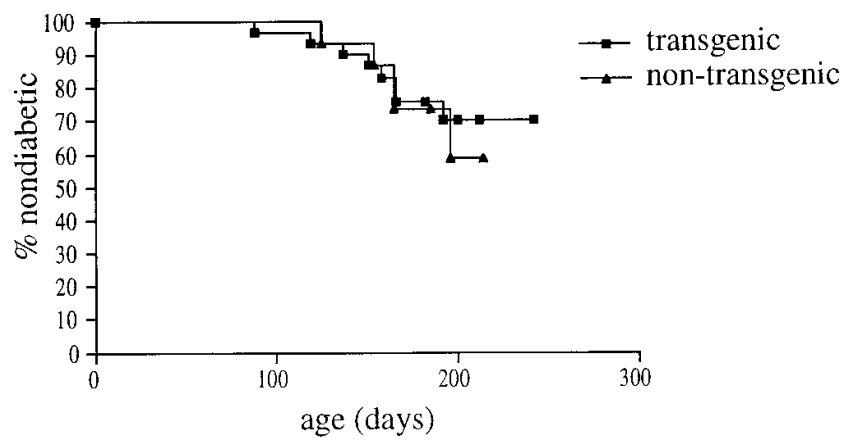

Figure 9. Spontaneous incidence of diabetes remains unchanged in RIP- $\Delta \gamma \mathrm{R}$ mice. Female RIP- $\Delta \gamma \mathrm{R}(+/+)$ and control mice were monitored weekly after $120 \mathrm{~d}$ of age for diabetes by urine glucose analysis. The survival curves were analyzed by the logrank test, and were found not to be significantly different $(P=0.7)$. The mean follow-up age is $185 \mathrm{~d}$.

responses that are not always identical to each other in other disease states (52). It is also possible that an as yet unidentified second ligand for the IFN- $\gamma$ receptor exists that substitutes for IFN- $\gamma$ in the IFN- $\gamma$-deficient animals. Because of these considerations and because we wished to test the relevance to diabetes of in vitro effects of IFN- $\gamma$ on beta cells, we chose an approach designed to produce IFN- $\gamma$-unresponsive beta cells, leaving the immune system intact. The approach of tissue-specific unresponsiveness to IFN- $\gamma$ allows elucidation of which cell type is the target of IFN- $\gamma$ relevant to the pathogenesis of IDDM. This cannot be achieved by transplantation of islets from knockout animals as there are many different cell types within the islet, including macrophages and endothelial cells, that are potential targets of IFN- $\gamma$ action.

This study demonstrates the power of genetic manipulation of the NOD model to address clinically important questions directly. The use of class I-deficient mice back-crossed onto the NOD model dramatically changed our understanding of the role of class I MHC expression and $\mathrm{CD}^{+} \mathrm{T}$ cells in the NOD, and the current data clarify that the requirement for class I expression is at basal levels only and have confirmed that IFN- $\gamma$ is likely to play at most a minor role by its action on beta cells. Clearly genetic manipulation of this sort is not applicable to IDDM in humans, in which virtually nothing definitive is known about pathogenesis beyond limited descriptive immunopathology. The challenge is to apply our understanding of diabetes pathogenesis in the NOD to human IDDM to enable rationally based treatment and prevention strategies.

\section{Acknowledgments}

We wish to thank Dr. Leigh A. Stephens, Dr. Jan Allison, Dr. Simon J. Foote, Ms. Vikki Marshall, and Ms. Rima Darwiche for expert advice and assistance. We also thank Dr. Anne Kelso, Dr. Diane Mathis, and Dr. William R. Heath for critical reading of the manuscript.

This work was supported by the National Health and Medical Research Council of Australia and the Juvenile Diabetes Foundation as part of a Diabetes Interdisciplinary Research Program.

\section{References}

1. Rabinovitch, A., W. Suarez-Pinzon, A. El-Sheikh, O. Sorensen, and R.F. Power. 1996. Cytokine gene expression in pancreatic islet-infiltrating leuko- 
cytes of BB rats: expression of Th1 cytokines correlates with beta-cell destructive insulitis and IDDM. Diabetes. 45:749-754.

2. Rabinovitch, A., W.L. Suarez-Pinzon, O. Sorensen, R.C. Bleackley, and R.F. Power. 1995. IFN-gamma gene expression in pancreatic islet-infiltrating mononuclear cells correlates with autoimmune diabetes in nonobese diabetic mice. J. Immunol. 154:4874-4882.

3. Wang, B., I. Andre, A. Gonzalez, J.D. Katz, M. Aguet, C. Benoist, and D. Mathis. 1997. Interferon-gamma impacts at multiple points during the progression of autoimmune diabetes. Proc. Natl. Acad. Sci. USA. 94:13844-13849.

4. Campbell, I.L., T.W. Kay, L. Oxbrow, and L.C. Harrison. 1991. Essential role for interferon-gamma and interleukin-6 in autoimmune insulin-dependent diabetes in NOD/Wehi mice. J. Clin. Invest. 87:739-742.

5. Debray-Sachs, M., C. Carnaud, C. Boitard, H. Cohen, I. Gresser, P. Bedossa, and J.F. Bach. 1991. Prevention of diabetes in NOD mice treated with antibody to murine IFN gamma. J. Autoimmun. 4:237-248.

6. Nicoletti, F., P. Zaccone, R. Di Marco, M. Di Mauro, G. Magro, S. Grasso, L. Mughini, P. Meroni, and G. Garotta. 1996. The effects of a nonimmunogenic form of murine soluble interferon-gamma receptor on the development of autoimmune diabetes in the NOD mouse. Endocrinology. 137:55675575 .

7. von Herrath, M.G., and M.B. Oldstone. 1997. Interferon-gamma is essential for destruction of beta cells and development of insulin-dependent diabetes mellitus. J. Exp. Med. 185:531-539.

8. Oldstone, M.B., M. Nerenberg, P. Southern, J. Price, and H. Lewicki. 1991. Virus infection triggers insulin-dependent diabetes mellitus in a transgenic model: role of anti-self (virus) immune response. Cell. 65:319-331.

9. Ohashi, P.S., S. Oehen, K. Buerki, H. Pircher, C.T. Ohashi, B. Odermatt, B. Malissen, R.M. Zinkernagel, and H. Hengartner. 1991. Ablation of "tolerance" and induction of diabetes by virus infection in viral antigen transgenic mice. Cell. 65:305-317.

10. Hultgren, B., X. Huang, N. Dybdal, and T.A. Stewart. 1996. Genetic absence of gamma-interferon delays but does not prevent diabetes in NOD mice. Diabetes. 45:812-817.

11. Eizirik, D.L., M. Flodstrom, A.E. Karlsen, and N. Welsh. 1996. The harmony of the spheres: inducible nitric oxide synthase and related genes in pancreatic beta cells. Diabetologia. 39:875-890.

12. Kaneto, H., J. Fujii, H.G. Seo, K. Suzuki, T. Matsuoka, M. Nakamura, H. Tatsumi, Y. Yamasaki, T. Kamada, and N. Taniguchi. 1995. Apoptotic cell death triggered by nitric oxide in pancreatic beta-cells. Diabetes. 44:733-738.

13. Dunger, A., J.M. Cunningham, C.A. Delaney, J.E. Lowe, M.H. Green, A.J. Bone, and I.C. Green. 1996. Tumor necrosis factor-alpha and interferongamma inhibit insulin secretion and cause DNA damage in unweaned-rat islets. Extent of nitric oxide involvement. Diabetes. 45:183-189.

14. Corbett, J.A., and M.L. McDaniel. 1995. Intraislet release of interleukin 1 inhibits beta cell function by inducing beta cell expression of inducible nitric oxide synthase. J. Exp. Med.181:559-568.

15. Nagata, S., and P. Golstein. 1995. The Fas death factor. Science. 267: 1449-1456.

16. Yamada, K, N. Takane-Gyotoku, X. Yuan, F. Ichikawa, C. Inada, and K. Nonaka. 1996. Mouse islet cell lysis mediated by interleukin-1-induced Fas. Diabetologia. 39:1306-1312.

17. Yagi, N., K. Yokono, K. Amano, M. Nagata, K. Tsukamoto, Y. Hasegawa, R. Yoneda, N. Okamoto, H. Moriyama, M. Miki, et al. 1995. Expression of intercellular adhesion molecule 1 on pancreatic beta-cells accelerates betacell destruction by cytotoxic T cells in murine autoimmune diabetes. Diabetes. 44:744-752.

18. Hanninen, A., S. Jalkanen, M. Salmi, S. Toikkanen, G. Nikolakaros, and O. Simell. 1992. Macrophages, T cell receptor usage, and endothelial cell activation in the pancreas at the onset of insulin-dependent diabetes mellitus. J. Clin. Invest. 90:1901-1910.

19. Itoh, N., T. Hanafusa, A. Miyazaki, J. Miyagawa, K. Yamagata, K. Yamamoto, M. Waguri, A. Imagawa, S. Tamura, M. Inada, et al. 1993. Mononuclear cell infiltration and its relation to the expression of major histocompatibility complex antigens and adhesion molecules in pancreas biopsy specimens from newly diagnosed insulin-dependent diabetes mellitus patients. J. Clin. Invest. 92:2313-2322.

20. Somoza, N., F. Vargas, C. Roura-Mir, M. Vives-Pi, M.T. FernandezFigueras, A. Ariza, R. Gomis, R. Bragado, M. Marti, D. Jaraquemada, and R. Pujol-Borrell. 1994. Pancreas in recent onset insulin-dependent diabetes mellitus. Changes in HLA, adhesion molecules and autoantigens, restricted T cell receptor V beta usage, and cytokine profile. J. Immunol. 153:1360-1377.

21. Kay, T.W., I.L. Campbell, L. Oxbrow, and L.C. Harrison. 1991. Overexpression of class I major histocompatibility complex accompanies insulitis in the non-obese diabetic mouse and is prevented by anti-interferon-gamma antibody. Diabetologia. 34:779-785.

22. O'Reilly, L.A., P.R. Hutchings, P.R. Crocker, E. Simpson, T. Lund, D. Kioussis, F. Takei, J. Baird, and A. Cooke. 1991. Characterization of pancreatic islet cell infiltrates in NOD mice: effect of cell transfer and transgene expression. Eur. J. Immunol. 21:1171-1180.

23. Ono, S.J., B. Issa-Chergui, E. Colle, R.D. Guttmann, T.A. Seemayer, and A. Fuks. 1988. IDDM in BB rats. Enhanced MHC class I heavy-chain gene expression in pancreatic islets. Diabetes. 37:1411-1418.
24. Ohashi, P.S., S. Oehen, P. Aichele, H. Pircher, B. Odermatt, P. Herrera, Y. Higuchi, K. Buerki, H. Hengartner, and R.M. Zinkernagel. 1993. Induction of diabetes is influenced by the infectious virus and local expression of MHC class I and tumor necrosis factor-alpha. J. Immunol. 150:5185-5194.

25. Vives-Pi, M., M.P. Armengol, L. Alcalde, M. Costa, N. Somoza, F. Vargas, D. Jaraquemada, and R. Pujol-Borrell. 1996. Expression of transporter associated with antigen processing- 1 in the endocrine cells of human pancreatic islets: effect of cytokines and evidence of hyperexpression in IDDM. Diabetes. 45:779-788.

26. Wicker, L.S., E.H. Leiter, J.A. Todd, R.J. Renjilian, E. Peterson, P.A. Fischer, P.L. Podolin, M. Zijlstra, R. Jaenisch, and L.B. Peterson. 1994. Beta 2-microglobulin-deficient NOD mice do not develop insulitis or diabetes. Diabetes. 43:500-504.

27. Serreze, D.V., E.H. Leiter, G.J. Christianson, D. Greiner, and D.C. Roopenian. 1994. Major histocompatibility complex class I-deficient NOD B2mnull mice are diabetes and insulitis resistant. Diabetes. 43:505-509.

28. Sumida, T., M. Furukawa, A. Sakamoto, T. Namekawa, T. Maeda, M. Zijlstra, I. Iwamoto, T. Koike, S. Yoshida, H. Tomioka, and M. Taniguchi. 1994 Prevention of insulitis and diabetes in beta 2-microglobulin-deficient non-obese diabetic mice. Int. Immunol. 6:1445-1449.

29. Katz, J., C. Benoist, and D. Mathis. 1993. Major histocompatibility complex class I molecules are required for the development of insulitis in non-obese diabetic mice.Eur. J. Immunol. 23:3358-3360.

30. Raulet, D.H. 1994. MHC class I-deficient mice. Adv. Immunol. 55:381-421.

31. Kay, T.W., J.L. Parker, L.A. Stephens, H.E. Thomas, and J. Allison. 1996. RIP-beta 2-microglobulin transgene expression restores insulitis, but not diabetes, in beta 2-microglobulin null nonobese diabetic mice. J. Immunol. 157: 3688-3693.

32. Kurts, C., W.R. Heath, F.R. Carbone, J. Allison, J.F. Miller, and H. Kosaka. 1996. Constitutive class I-restricted exogenous presentation of self antigens in vivo. J. Exp. Med. 184:923-930.

33. Dighe, A.S., D. Campbell, C.S. Hsieh, S. Clarke, D.R. Greaves, S. Gordon, K.M. Murphy, and R.D. Schreiber. 1995. Tissue-specific targeting of cytokine unresponsiveness in transgenic mice. Immunity. 3:657-666.

34. Dighe, A.S., M.A. Farrar, and R.D. Schreiber. 1993. Inhibition of cellular responsiveness to interferon-gamma (IFN gamma) induced by overexpression of inactive forms of the IFN gamma receptor. J. Biol. Chem. 268:1064510653.

35. Dietrich, W.F., J. Miller, R. Steen, M.A. Merchant, D. Damron-Boles, Z. Husain, R. Dredge, M.J. Daly, K.A. Ingalls, et al. 1996. A comprehensive genetic map of the mouse genome. Nature. 380:149-152.

36. Church, G.M., and S. Kieffer-Higgins. 1988. Multiplex DNA sequencing. Science. 240:185-188.

37. Richterich, P., and G.M. Church. 1993. DNA sequencing with direct transfer electrophoresis and nonradioactive detection. Methods Enzymol. 218: 187-222.

38. Lake, S.P., J. Anderson, J. Chamberlain, S.J. Gardner, P.R. Bell, and R.F. James. 1987. Bovine serum albumin density gradient isolation of rat pancreatic islets. Transplantation. 43:805-808.

39. Evan, G.I., G.K. Lewis, G. Ramsay, and J.M. Bishop. 1985. Isolation of monoclonal antibodies specific for human c-myc proto-oncogene product. $\mathrm{Mol}$. Cell. Biol. 5:3610-3616.

40. LeClaire, R.D., M. Basu, D.M. Pinson, M.L. Redick, J.S. Hunt, P.J. Zavodny, J.L. Pace, and S.W. Russell. 1992. Characterization and use of monoclonal and polyclonal antibodies against the mouse interferon-gamma receptor. J. Leukoc. Biol. 51:507-516.

41. Ozato, K., N.M. Mayer, and D.H. Sachs. 1982. Monoclonal antibodies to mouse major histocompatibility complex antigens. Transplantation. 34:113-120.

42. Eisenbarth, G.S., F.S. Walsh, and M. Nirenberg. 1979. Monoclonal antibody to a plasma membrane antigen of neurons. Proc. Natl. Acad. Sci. USA. 76: 4913-4917.

43. Pipeleers, D.G., P.A. in't Veld, M. Van de Winkel, E. Maes, F.C. Schuit, and W. Gepts. 1985. A new in vitro model for the study of pancreatic A and B cells. Endocrinology. 117:806-816.

44. Schreiber, E., P. Matthias, M.M. Muller, and W. Schaffner. 1989. Rapid detection of octamer binding proteins with mini-extracts, prepared from a small number of cells. Nucleic Acids Res. 17:6419.

45. Pearse, R.N., R. Feinman, K. Shuai, J. Darnell, Jr., and J.V. Ravetch 1993. Interferon gamma-induced transcription of the high-affinity Fc receptor for IgG requires assembly of a complex that includes the 91-kDa subunit of transcription factor ISGF3. Proc. Natl. Acad. Sci. USA. 90:4314-4318.

46. Charlton, B., and T.E. Mandel. 1988. Progression from insulitis to betacell destruction in NOD mouse requires L3T4+ T-lymphocytes. Diabetes. 37: 1108-1112.

47. Darnell, J., Jr., I.M. Kerr, and G.R. Stark. 1994. Jak-STAT pathways and transcriptional activation in response to IFNs and other extracellular signaling proteins. Science. 264:1415-1421.

48. Rabinovitch, A. 1996. Roles of cell-mediated immunity and cytokines in the pathogenesis of insulin-dependent diabetes mellitus. In Diabetes MellitusA Fundamental and Clinical Text. D. LeRoith, S.I. Taylor, and J.M. Olefsky, editors. Lippincott-Raven Publishers, Philadelphia. 314-325.

49. Pankewycz, O.G., J.X. Guan, and J.F. Benedict. 1995. Cytokines as me- 
diators of autoimmune diabetes and diabetic complications. Endocr. Rev. 16: $164-176$

50. Harrison, L.C., I.L. Campbell, P.G. Colman, N. Chosich, T.W.H. Kay, B.D. Tait, R.K. Bartholomeusz, H.J. De Aizpurua, J.L. Joseph, S. Chu, and W.E. Kielczynski. 1990. Type 1 diabetes: immunopathology and immunotherapy. Adv. Endocrinol. Metab. 1:35-94.

51. Kay, T., H.L. Chaplin, J.L. Parker, L.A. Stephens, and H.E. Thomas. 1997. CD4(+) and CD8(+) T lymphocytes-clarification of their pathogenic roles in diabetes in the NOD mouse. Res. Immunol. 148:320-327.
52. Swihart, K., U. Fruth, N. Messmer, K. Hug, R. Behin, S. Huang, G. Del Giudice, M. Aguet, and J.A. Louis. 1995. Mice from a genetically resistant background lacking the interferon gamma receptor are susceptible to infection with Leishmania major but mount a polarized T helper cell 1-type CD4+ T cell response. J. Exp. Med. 181:961-971.

53. Hamaguchi, K., H.R. Gaskins, and E.H. Leiter. 1991. NIT-1, a pancreatic beta-cell line established from a transgenic NOD/Lt mouse. Diabetes. 40: 842-849. 